Araşturma Makalesi / Research Article

Geliş tarihi / Received: 20-11-2020

Kabul tarihi / Accepted: 11-05-2021

Atıf İçin: Altun, Y., Çatal, M., 2021. Materyal Destekli Öğretim Yönteminin İlköğretim 8. Sınıf Matematik Öğretiminde Öğrenci Başarısına Etkisi. Iğdır Üniversitesi Fen Bilimleri Enstitüsü Dergisi, 11(3): 2290-2300.

To Cite: Altun, Y., Çatal, M., 2021. The Effect on Student Success of Material Supported Teaching Method in Elementary 8th Class Mathematics Teaching. Journal of the Institute of Science and Technology, 11(3): 2290-2300.

\title{
Materyal Destekli Öğretim Yönteminin İlköğretim 8. Sınıf Matematik Öğretiminde Öğrenci Başarısına Etkisi
}

\section{Yener ALTUN ${ }^{1 *}$, Mahfuz ÇATAL ${ }^{2}$}

ÖZET: Matematik öğretiminde matematik derslerinin kendine has soyut yapısı bu dersin anlaşılmasında güçlüklere neden olmaktadır. $\mathrm{Bu}$ bağlamda matematik öğretiminin konuya uygun materyallerle somutlaştırılarak desteklenmesi, zengin öğrenme yaşantılarının sağlanması son derece önemlidir. İlköğretim 8. sınıf matematik konularının öğretiminde materyal destekli öğretimin öğrenci başarısına etkisini amaçlayan bu çalışma dört bölümden oluşmaktadır. Birinci bölümde araştırmanın amacı, problemi ve varsayımları verilmiş ve literatür taraması yapılmıştır. İkinci bölümde araştırmada kullanılan yöntem ile ilgili bilgiler ele alınmaktadır. Üçüncü bölümde Van il merkezindeki bir ilköğretim okulunda uygulanan testler ile elde edilen bulgulara ve bulguların yorumlanmasına yer verilmektedir. Dördüncü bölümde, sonuç yer almaktadır.

Anahtar Kelimeler: Matematik, Matematik öğretimi, Materyal, Başarı

\section{The Effect on Student Success of Material Supported Teaching Method in Elementary 8th Class Mathematics Teaching}

\begin{abstract}
The unique abstract structure of mathematics lessons in mathematics teaching causes difficulties in understanding this lesson. In this context, it is extremely important to support mathematics teaching by concretizing it with materials suitable for the subject and providing rich learning experiences. This study, which aims at the effect on student success of material-supported teaching on in teaching elementary 8th class mathematics subjects, consists of four sections. In the first section, the aim, problem and assumptions of the research are given and a literature review has been made. In the second section, information about the method used in the research is discussed. In the third section, the findings obtained through the tests applied in a central primary school in Van province and interpretations of the findings are given. The fourth section contains the result.
\end{abstract}

Keywords: Mathematics, Mathematics teaching, Material, Success

${ }^{1}$ Yener ALTUN (Orcid ID: 0000-0003-1073-5513), Yüzüncü Y1l Üniversitesi, Erciş İşletme Fakültesi, İşletme Bölümü, Van, Türkiye

${ }^{2}$ Mahfuz ÇATAL (Orcid ID: 0000-0001-9970-4072), Yüzüncü Yıl Üniversitesi, Fen Bilimleri Enstitüsü, İstatistik Anabilim Dalı, Van, Türkiye

*Sorumlu Yazar/Corresponding Author: Yener ALTUN, yeneraltun@yyu.edu.tr

Bu çalışma Mahfuz ÇATAL’ın Yüksek Lisans tezinden üretilmiştir.

ETİK KURUL ONAYI: Bu makale için "Van Yüzüncü Yıl Üniversitesi Rektörlüğü Sosyal ve Beşeri Bilimleri Yayın Etik Kurulu” tarafından 21/08/2019 tarih ve 2019/06-06 sayılı kararı ile Etik Kurul Onayı almıştır. 


\section{GíRiş}

Çağımızda teknoloji, ekonomi, ulaşım, iletişim, tarım, bilim ve kentleşme alanlarında yaşanan hızlı gelişmeler toplumların matematiğe olan ihtiyacını ve ilgisini artırmıştır. Yeni yetişen nesillere, biçimsel bir bilim dalı olan matematiğin aktarılması daha da kritik bir önem taşımaktadır. Bu anlamda matematiğin teknolojik, sosyal ve kültürel gelişmelere katkısının hangi ölçüde olabildiği, matematikten daha etkili nasıl fayda sağlanacağı fikri toplumları ve bilim adamlarını matematik öğretiminde yeni arayışlara sevk etmiştir. Matematik eğitiminde klasik öğretim yönteminin, günümüzün değişen ihtiyaçlarına yanıt vermediği, başlangıçta işlem yapma ve hesap yapabilme becerileri ilk plandayken artık akıl yürütme, tahmin yapma, problem çözme, desen arama gibi beceriler büyük bir öneme sahiptir (Olkun ve Toluk, 2003). Günümüz dünyasında gelişen demokratik ve insan hakları değerleri bireyi ön plana almaktadır. Bu da toplumların eğitime bakış açısını ve beklentilerini değiştirmekte eğitim sistemlerinde yeni arayışlara yönlendirmektedir. Ezbere ve aktarıma dayalı öğretim metotları ve monolog ders işlenişin aksine öğrencilerin aktif katılımına dayalı öğretim metotlarına ve ders içeriklerine geçişi sağlanmalıdır. Matematik öğretiminde ne öğrendiğimizden çok nasıl öğrendiğimiz çok önemlidir. Soyut olan matematik konularının çeşitli uygun materyallerle somutlaştırılması için öğretim metotlarında ve ders içeriklerinde birtakım değişiklerin yapılması kaçınılmazdır. Matematik öğretiminde öğretmen merkezli metotlar yerine öğrenci merkezli metotlar ön plana çıkmaktadır. Öğretmen ve öğrenci rollerinde değişime paralel olarak öğrencilerden artık bilgiyi pasif bir şekilde almak yerine bilgiyi sorgulayan, tartışan, iletişim kuran, çıkarımda bulunan, arkadaşları ve öğretmeni ile iş birliği yapan aktif katılımcılar olması istenmektedir. Öğrenciler kendi öğrenmelerini inşa eden, plan yapan, öğrenmelerini organize eden, kendi çalışmalarını değerlendiren ve öğrenmenin sorumluluğunu alan kişiler olarak tanımlanmaktadır.

Geleneksel öğretim yaklaşımı bilgi ve öğretmen merkezli esasa sahiptir. Öğretmen her şeyi bilen bilginin otoritesi olarak kabul edilmektedir. Bilgi ise değişmez ve sorgulanmaz olarak görülmektedir. Günümüz yaklaşımların da ise öğretmenlerden öğrencisine cesaret veren, öğrenme ortamını organize eden bilgileri hazır çözümler şeklinde vermek yerine öğrenmeye rehberlik eden olması istenmektedir. Bilgi ise değişime açık sorgulanır bir içeriğe dönüşmüştür. Bilgi ürün olmaktan çok süreç olarak görülmektedir. Bugünün, öğrencileri matematiksel ve bilimsel bilgiyi inşa ediyorlar. Günümüz eğitim perspektifi öğrenciler tarafından tamamlanması gereken önceden düzenlenmiş görevlere odaklanmaktan daha çok öğrenme sürecine ve öğrencilerin önceki eğitim deneyimine yoğunlaşmaya odaklanmıştır (Podolak ve ark., 2014). Bu doğrultuda geleneksel eğitimin öğrencilerin az da olsa ihtiyaçlarını da karşılayamadığı sınırlılıklar nedeniyle bazı sınıf içi etkinliklerde yürütülemeyebilir. Bu durumda alternatif eğitim modellerinin de öğretici tarafından dikkate alınması gerekir (Eygü ve Karaman, 2013).

Matematik, insanın zihinsel anlamda ortaya koyduğu bir sitemdir. Yapı olarak soyut olan matematik öğrenme ve öğretilmesi zor olup materyaller ve oyunlar ile somutlaştırılması gerekir (Acar, 2005). Öğretim materyali, en geniş tanımıyla, eğitim-öğretim sürecini aktif kılmak açısından yararlanılan her türlü araç gereçtir. Amaca uygun materyal kullanımı, ele alınacak konuya ilişkin alt konular arasındaki bağlantıları modellemek, öğreneni aktif kılmak ve anlaşılması güç konuları somutlaştırmaktır. $\mathrm{Bu}$ nedenle öğretimi etkin hale getirmek, verimliliği çoğaltmak temel amaca elverişli her türlü destek sağlayıcı nesne bir öğretim materyali olarak görülebilir (Yıldız, 2004). Günümüzde beklenen öğretim ezberci, pasif, kısa yoldan en çabuk cevap verebilen öğrencilerin aksine derse etkin katılım sağlayan, eleştirel düşünebilen, dikkate alınan bir problemin hesaplanmasında farklı yollar üretebilen öğrenciler yetiştirebilmektir. Bu amaç doğrultusunda matematik öğretim programları 
yapılandırmacılık yaklaşımına dayalı olarak yeniden hazır hale getirilmiştir (Güler ve ark., 2013). Matematikle ilgili olumsuz tutum ve önyargılara neden olan ve yapılan araştırmalarla desteklenen klasik matematik öğretiminin değişimi için son yıllarda birçok araştırma ve çalışmaya rastlanmaktadır (Moyer, 2001; Baki, 2003; Pesen, 2003; Tabuk, 2003; Gündüz ve Odabaş1, 2004; Cengizhan, 2008; Özmantar ve Bingölbali, 2009; Bozkurt ve Akalın, 2010; Uysal Koğ, 2012; Aydın ve Doğan, 2012; Lerman, 2014; Altun, 2016).

$\mathrm{Bu}$ çalışmada, materyal destekli öğretim yöntemi ile ilköğretim matematik konularının öğretiminin, öğrenci başarısına doğrudan etkisinin incelenmesi amaçlanmıştır. Bu amaca yönelik olarak;

a. Materyal kullanılarak öğretimin öğrenci başarısına etkisinin tespiti,

b. Klasik öğretim yöntemi ile materyal destekli öğretim yönteminin eğitim-öğretimdeki etkisinin kiyaslanmasi,

c. Materyal destekli öğretimde, öğrencilere matematiği sevdirmeyi, matematiğe karşı önyargıları kırmayı bilimsel, sanatsal ve ekonomik faaliyetlerimizde bize yardımcı bir araç olduğu gerçeğinin kavratılmas1,

d. Klişe haline gelmiş konu odaklı öğretim modelinin aksine yararlanabileceğimiz, yukarıda vurgulanan amaca yönelik yeni bir bakış açısıyla model geliştirilmesine katkı sağlanması,

e. İlgili literatüre bu anlamda bir katkıda bulunması hedeflenmektedir.

\section{Araştırmanın Problemi}

$\mathrm{Bu}$ çalışmada, materyal destekli öğretimin ilköğretim matematik konularının öğretimindeki etkisini ortaya koymak ve bunu analiz etmek problem olarak tanımlanmıştır. Bunun çözümü için, ilköğretim 8. sınıf matematik dersinde yer alan çarpanlar ve katlar, üslü ifadeler ve köklü ifadeler konularının, materyal destekli öğretimi ile klasik öğretim yöntemi arasındaki ilişkinin varlığı aşağıda maddeler halinde verilen sorular ile incelenmiştir.

a. Ön test sonuçları açısından materyal destekli öğretim gören deney grubu ile kontrol (klasik yöntemle ders anlatılan) grubu arasında anlamlı bir fark var mıdır?

b. Son test sonuçları açısından materyal destekli öğretim gören deney grubu ile kontrol grubu arasında anlamlı bir fark var midır?

c. Deney ve kontrol grubundaki öğrencilerin öğrenmelerinin kalıcılık düzeyleri arasında anlamlı bir fark var midır?

d. İstatistiksel olarak kontrol grubu öğrencilerinin ön test-son test başarı puanları arasında anlamlı bir fark var midir?

e. İstatistiksel olarak deney grubu öğrencilerinin ön test-son test başarı puanları arasında anlamlı bir fark var midır?

f. Klasik öğretim yöntemine oranla, materyal destekli öğretimin öğrenci başarısı üzerinde etkisi var midır?

\section{Araştırmanın Varsayımları}

Aşağıda verilen varsayım ve kabuller bu çalışma için ön koşul olarak dikkate alınmıştır.

i. Araştırmaya konu olan materyal destekli öğretim ve klasik öğretim yöntemi ile öğretim sürecinde, deney ve kontrol grubu olarak adlandırılan her iki sınıfa da aynı öğretmen dersi işlemiştir.

ii. Ele alınan bu çalışmada uygulama yapılmadan önce deney ve kontrol gruplarında yer alan deneklerin (öğrencilerin) çarpanlar ve katlar, üslü ifadeler ve köklü ifadeler konularında yeterli bilgiye sahip olmadıkları kabul edilmiştir. 
iii. Değerlendirme testlerine öğrencilerin vermiş oldukları yanıtlar, onların gerçek tutum ve davranışlarını aksettiği kabul edilmiştir.

iv. $\mathrm{Bu}$ araştırma kontrol gruplu yapılarak ön, son ve hatırlama test modeli kullanılarak incelenmiştir. 30 soru üzerinden hazırlanan testler için her bir soru 1 puan üzerinden değerlendirmeye alınmıştır.

\section{MATERYAL VE METOT}

Bu bölüm; söz konusu çalışmanın amacı doğrultusunda gerçekleştirilmesi planlanan hedeflere ulaşmak için yapılan çalışmaları (araştırmanın nasıl yürütüldüğü, deneklerin nasıl seçildiği, ölçme araçlarının nasıl geliştirildiği, verilerin analizinde kullanılan istatistiksel yöntem ve teknikler, vb.) kapsamaktadir.

Bu çalışmanın etik kurul onayı, Van Yüzüncü Yıl Üniversitesi Sosyal ve Beşeri Bilimleri Yayın Etik Kurulu'ndan 21.08.2019 tarih ve 2019/06-06 nolu kararla alınmıştır.

\section{Veri Toplama Aracı}

Çalışma boyunca deney ve kontrol grubunda yer alan deneklerin başarı düzeylerini belirlemek için, "Akademik Başarı Testi” uygulanmıştır. Söz konusu bu test hazırlanırken MEB (Milli Eğitim Bakanlığı) ders kitabı olarak onaylı ve 2018-2019 eğitim-öğretim y1lında ortaokul 8. sınıflarda mevcut olan öğretmen kılavuz ve matematik ders kitapları ile LGS sınavlarına hazırlık kitaplarından yer alan çarpanlar ve katlar, üslü ifadeler ve köklü ifadeler konuları dikkate alınmıştır. Akademik başarı testi, sayılar ve işlemler öğrenme alanındaki kazanımlara yönelik olarak, çoktan seçmeli 30 sorudan oluşmaktadır. Sorular puanlanırken yanlış cevap 0 puan ve doğru cevap 1 puan olacak biçimde kodlanmıştır.

\section{Araştırmanın Uygulanması}

Araştırmada ilk olarak, "Akademik Başarı Testi” hazırlanmıştır. Matematik dersine ilişkin öğretim programında (MEB, 2018) 8. sınıf sayılar ve işlemler öğrenme alanında yer alan kazanımlara programda 50 ders saati süre ayrılmıştır. Matematik dersi haftalık 4 ders saati olarak uygulanmıştır. Söz konusu araştırmanın gerçekleştirilmesi amacı ile aşağıda belirtilen adımlar izlenmiştir:

i. Çalışma, 2019 - 2020 Eğitim-Öğretim yılı güz dönemi içinde, Van Tuşba ilçesinde yer alan Zeve ilköğretim okulu 8. sınıflardan seçilen iki sınıfta (8/B ve 8/C) yapılmıştır.

ii. Çalışmada elde edilen sonuçların standartlara uygun şekilde değerlendirilmesi için ilk olarak materyal destekli öğretim yöntemi uygulanmadan önce söz konusu konular ile ilgili 40 adet test sorusu hazırlanmıştır. Daha sonra ele alınan bu test sorularının güçlük derecesini ve uygulanabilirliğini test etmek için Van Edremit Mizancı Murat Anadolu İmam Hatip Lisesi 9. Sınıf öğrencileri üzerinde uygulama yapılmıştır. Uygulamada elde edilen sonuçlar madde analizi tekniği ile değerlendirilerek soru sayısı 30'a düşürülmüştür. Yapılan güvenirlilik analizi sonucu testin Cronbach's Alpha değeri 0.870 olarak bulunmuştur (Çizelge 1). Bu değer, 0.87 > 0.70 olduğu için testin güvenilir olduğu söylenebilir.

iii. Madde analizi uygulanarak seçilmiş 30 soruluk test soruları, araştırmanın ele alındığı iki sınıftaki deneklere uygulanmıştır. Bu uygulamadaki değerlendirme çalışmada "Ön Test" olarak ifade edilmiştir.

iv. Ön Test değerlendirmesi sonucunda aritmetik ortalaması küçük olan 8/C sınıfı "Deney Grubu", 8/B sınıfı ise "Kontrol Grubu" olarak adlandırılacaktır. 
v. Çarpanlar ve katlar, üslü ifadeler ve köklü ifadeler konuları üzerinde Deney Grubu'na materyal destekli öğretim yöntemi, Kontrol Grubu’na ise klasik öğretim yöntemi kullanılarak öğrencilere aktarılmıştır.

vi. Materyal kullanılarak işlenecek konular matematiksel hikâyeler, bilgisayar uygulamaları (geogebra), hatırlatıcı karton malzemeler, şarkı, hangi alanlarda kullanıldığıyla ilgili yazılar, çalışma yaprakları vb. materyaller kullanılmıştır.

vii. Ön Test için hazırlanan test soruları, konuların anlatımlarını takip eden süreçten sonra Deney ve Kontrol gruplarındaki öğrencilere tekrar uygulanmıştır. Konuların anlatılmasından sonra bu iki sınıfa da uygulanan değerlendirme çalışmada, "Son Test" olarak ifade edilmiştir.

viii. $\mathrm{Bu}$ çalışmada elde edilen sonuçları sağlıklı bir şekilde değerlendirilmek için başlangıçta Ön Testte sunulan sorular, her iki sınıfta yer alan deneklere Son Testin uygulanmasından 30 gün sonra yeniden uygulanmıştır. Bu uygulamadaki değerlendirme çalışmada "Hatırlama Test" olarak ifade edilmiştir.

ix. Çalışmada Ön, Son ve Hatırlama Test olarak adlandırılan bu testlerin analizleri sonrasında ulaşılan veriler elverişli bir istatistik programında (SPSS 20.0) bağımlı örneklem t testi (paired samples $t$ test) ve bă̆ımsız örneklem t testi (independent samples t test) ile analiz edilmiştir.

x. Çalışmada elde edilen bağımlı örneklem $t$ testi ve bağımsız örneklem t testi sonuçları 0.05 anlamlılık düzeyi esas alınarak değerlendirmeye alınmıştır. Burada, anlamlılık düzeyi 0.05'den küçük olduğunda, gruplar arasındaki farkın istatistiksel olarak önemli olduğu kabul edilmiştir. Öte yandan anlamlılık düzeyinin 0.05 'den büyük olması halinde ise farkın istatistiksel olarak önemsiz olduğu kabul edilmiştir.

Çizelge 1. Güvenirlilik analizi

Cronbach's Alpha

0.870

\section{Madde Sayısı}

40

\section{Araştırmanın Evreni ve Örneklemi}

$\mathrm{Bu}$ çalışmanın evrenini Milli Eğitim Bakanlığı ilköğretim 8. sınıf matematik dersini alan öğrenciler oluşturmaktadır. Yapılan bu çalışmanın örneklemini, 2019 - 2020 Eğitim-Öğretim yılı güz dönemi içinde, Van ili Tuşba İlçesi'nde yer alan Zeve İlköğretim okulu, 8. sınıflardan seçilen 8/B ve $8 / C$ sınıfı öğrencileri oluşturmaktadır.

\section{Verilerin Analizi}

SPSS 20.0 programı ile çarpanlar ve katlar, üslü ve köklü ifadeler ile ilgili testler sonucunda elde edilen veriler analiz edilmiştir. Sunulan testlerdeki her bir soru 1 puan olarak alınmış ve toplamda 30 puan üzerinden değerlendirilmeye tabi tutulmuştur. Çalışmada elde edilen analizler kapsamında ilk olarak her bir test için ortalama, standart sapma ve varyans değerleri bulunmuştur. Grup içi ve gruplar arası olmak üzere veri analizleri iki bölüm şeklinde SPSS bilgisayar programı ile gerçekleştirilmiştir. Grup içinde bağımlı örneklem $\mathrm{t}$ testi ve gruplar arasında bağımsız örneklem t testi ile 0.05 anlamlılık düzeyi esas alınarak Ön, Son ve Hatırlama Test sonuçları değerlendirilmiştir.

\section{BULGULAR VE TARTIŞMA}

Bu bölümde, deney ve kontrol gruplarına uygulanmış olan ön, son ve hatırlama test sonuçları dikkate alınmıştır. Çalışmada elde edilen sonuçlar, grup içi ve gruplar arası olmak üzere iki başlıkta ele alınmıştır. 


\section{Gruplar Arası Bulgular}

Deney ve kontrol grubu olarak seçilen her iki sınıfa uygulanmış olan ön, son ve hatırlama test sonuçları, bu iki grup arasında incelenecektir. İlk olarak, Şekil 1'de de görüldüğü gibi deney ve kontrol gruplarına uygulanan ön, son ve hatırlama testlerinin aritmetik ortalama değerleri sunulmaktadır. Şekil 1'de dikkat edildiğinde deney grubunun ön test ortalamasının kontrol grubunun ön test ortalamasına oranla daha düşük olduğu açıkça görülmektedir. Çalışma sürecinde deney grubuna uygulanan materyal destekli öğretim yöntemi ile öğretim sonrası yapılan son test sonuçları bu grubun ortalamasını 11.40 'den 22.77 'e yükseltmiştir. Klasik öğretim yöntemi ile öğretim sonrası kontrol grubunun aritmetik ortalaması ise öğretim öncesi 12.73 iken öğretim sonrası 20.47 'e yükseldiği görülmektedir. Her iki gruba son test uygulandıktan 30 gün sonra uygulanan hatırlama test ortalama değerleri sirasıyla 21.47 ve 18.73 olarak bulunmuştur. Mevcut durumda, kontrol grubu ile deney grubu kiyaslandığında, uygulama öncesi başarı ortalaması düşük olan deney grubunun kontrol grubuna göre uygulama sonrası durumda başarı ortalamasının daha yüksek olduğu ve verilen öğretimin daha kalıcı olduğu tespit edilmiştir.

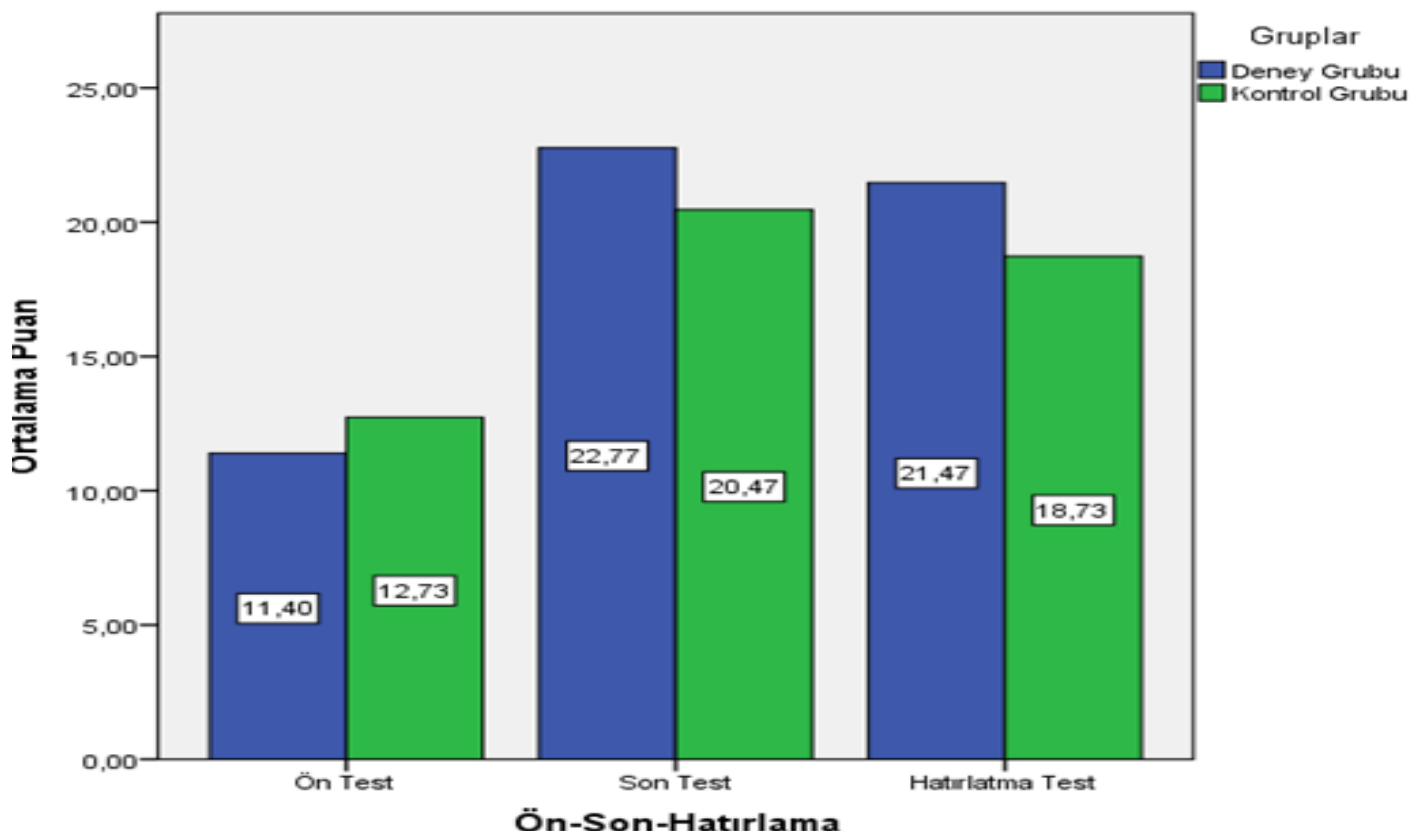

Şekil 1. Gruplar arası Ön-Son-Hatırlama testi karşılaştırması.

\section{Ön test bulgular}

Materyal destekli öğretim ve klasik öğretimin öğretim öncesi deney ve kontrol gruplarına uygulanan ön test tanımlayıcı istatistik sonuçları Çizelge 2'de gösterilmiştir. Çizelge 2'deki gibi sırasıyla deney ve kontrol gruplarına ait ön test ortalama değerleri 11.4000 ve 12.7333 , standart sapma değerleri 3.29681 ve 4.37022 ve varyans değerleri ise 10.869 ve 19.099 olarak hesaplanmıştır.

Çizelge 2. Ön test tanımlayıcı istatistikler

\begin{tabular}{lcccc}
\hline & N & Ortalama & Standart Sapma & Varyans \\
\hline Deney Grubu & 30 & 11.4000 & 3.29681 & 10.869 \\
Kontrol Grubu & 30 & 12.7333 & 4.37022 & 19.099 \\
\hline
\end{tabular}

Çizelge 3. Ön test normallik testi bulguları

\begin{tabular}{lcccccc}
\hline & \multicolumn{3}{c}{ Kolmogorov-Smirnov } & \multicolumn{3}{c}{ Shapiro-Wilk } \\
\hline & İstatistik & df & $p$-value & İstatistik & df & $p$-value \\
Keney Grubu & 0.115 & 30 & 0.200 & 0.960 & 30 & 0.314 \\
\hline
\end{tabular}


Her iki grup arasında yapılan ön testler arasında istatistiki olarak herhangi bir ilişkinin var olup olmadığının belirlenmesi için $\alpha=0.05$ anlamlılık düzeyi göz önünde bulundurularak bağımsız örneklem $t$ testi uygulanmıştır. Bağımsız örneklem $t$ testi'nin uygulanması için başarı değişkeninin normal dağ 1 lım göstermesi gerekir. Çizelge 3 de dağılımın normal olduğu gösterilmiştir.

Çizelge 3'te deney grubu öğrencilerinin başarı puanlarının Kolmogorov-Smirnov istatistiğine göre anlamlılık düzeyi $\alpha<p$ olarak çıkmıştır. Bu başarı puanlarının normal dağılımla arasındaki farkın önemsiz olduğunu göstermiştir. Kontrol grubu öğrencilerinin başarı puanlarının Shapiro-Wilk istatistiğine göre anlamlılık düzeyi $\alpha<p$ olarak çıkmıştır. Bu başarı puanlarının normal dağılıma sahip olmadığını göstermektedir.

Yapılan analiz sonucunda, 58 serbestlik derecesine sahip olan gruplar arası ön test sonuçları için, $t$ değeri -1.334 olup anlamlılık düzeyi $(p)$ ise 0.187 olarak bulunmuştur (Çizelge 4). Bu durum 0.05 anlamlılık derecesi esas alındığında her iki grubun istatistiksel anlamda ön test sonuçları arasındaki farkın önemsiz $(\alpha<p)$ olduğunu ortaya koymaktadır.

Çizelge 4. Ön test gruplar arası bă̆ımsız örneklem t testi bulguları

\begin{tabular}{lccc} 
& \multicolumn{4}{c}{ t-test for equality of means } \\
\cline { 2 - 5 } & $\mathbf{t}$ & $\mathbf{d f}$ & p-value (2-tailed) \\
\hline Başarı & -1.334 & 58 & 0.187 \\
\hline
\end{tabular}

\section{Son test bulgular}

Çizelge 5'de materyal destekli ve klasik öğretim yöntemi ile öğretim sonrası her iki gruba uygulanan son test sonuçları dikkate alındığında Deney ve Kontrol gruplarının ortalama değerleri sırasıyla 22.7667 ve 20.4667 olarak elde edilmiştir. Yine bu gruba ait standart sapma değerleri sirasiyla 3.94517 ve 4.76144 olup varyans değerleri ise 15.564 ve 22.671 'dir.

Çizelge 5. Son test tanımlayıcı istatistikler

\begin{tabular}{lcccc}
\hline & N & Ortalama & Standart Sapma & Varyans \\
\hline Deney Grubu & 30 & 22.7667 & 3.94517 & 15.564 \\
Kontrol Grubu & 30 & 20.4667 & 4.76144 & 22.671 \\
\hline
\end{tabular}

Çizelge 6'de deney grubu öğrencilerinin başarı puanlarının Kolmogorov-Smirnov istatistiğine göre anlamlılık düzeyi $\alpha<p$ olarak çıkmıştır. Bu başarı puanlarının normal dağılımla arasındaki farkın önemsiz olduğunu göstermiştir. Kontrol grubu öğrencilerinin başarı puanlarının KolmogorovSmirnov istatistiğine göre anlamlılık düzeyi $\alpha<p$ olarak çıkmıştır. Bu başarı puanlarının normal dağılıma sahip olduğunu göstermektedir.

Çizelge 6. Son test normallik testi bulguları

\begin{tabular}{lllllll}
\hline & \multicolumn{3}{c}{ Kolmogorov-Smirnov } & \multicolumn{3}{c}{ Shapiro-Wilk } \\
\hline & İstatistik & df & $\boldsymbol{p}$-value & İstatistik & df & $\boldsymbol{p}$-value \\
Deney Grubu & 0.157 & 30 & 0.057 & 0.908 & 30 & 0.013 \\
Kontrol Grubu & 0.136 & 30 & 0.164 & 0.951 & 30 & 0.181 \\
\hline
\end{tabular}

Yapılan analiz sonucunda, Çizelge 7.'da 58 olan serbestlik derecesine sahip olan gruplar arası son test sonuçları için, $t$ değeri 2.037 ve anlamlılık düzeyi $(p)$ ise 0.023 olarak bulunmuştur. Bu durum 0.05 anlamlılık derecesi esas alındığında deney ve kontrol gruplarının son test sonuçları arasındaki farkın istatistiksel anlamda önemli $(p<\alpha)$ olduğunu ortaya koymaktadır. 
Çizelge 7. Son test gruplar arası bağımsız örneklem t testi bulguları

\begin{tabular}{cccc}
\hline \multicolumn{4}{c}{ t-test for Equality of Means } \\
\hline \multirow{3}{*}{ Başarı } & $t$ & $\mathrm{df}$ & $p$-value (2-tailed) \\
\hline
\end{tabular}

\section{Hatırlama test bulgular}

Çalışma boyunca son test uygulandıktan 30 gün sonra deney ve kontrol gruplarına uygulanmış olan hatırlama test sonuçlarına ilişkin istatistiksel analiz sonuçları Çizelge 8'de sunulmaktadır. Çizelge 8 'de her iki grubun hatırlama test ortalama değerleri sırasıyla 21.4667 ve 18.7333 olarak bulunmuştur. $\mathrm{Bu}$ iki gruba ait standart sapma değerleri sirasıyla 4.57680 ve 4.22581 olup varyans değerleri ise sirasiyla 20.947 ve 17.857 'dir.

Çizelge 8. Hatırlama test tanımlayıcı istatistikler

\begin{tabular}{lcccc}
\hline & $\mathbf{N}$ & Ortalama & Standart sapma & Varyans \\
\cline { 2 - 5 } Deney Grubu & 30 & 21.4667 & 4.57680 & 20.947 \\
Kontrol Grubu & 30 & 18.7333 & 4.22581 & 17.857 \\
\hline
\end{tabular}

Çizelge 9'da deney grubu öğrencilerinin başarı puanlarının Kolmogorov-Smirnov istatistiğine göre anlamlılık düzeyi $\alpha<p$ olarak çıkmıştır. Bu başarı puanlarının normal dağılımla arasındaki farkın önemsiz olduğunu göstermiştir. Kontrol grubu öğrencilerinin başarı puanlarının KolmogorovSmirnov istatistiğine göre anlamlılık düzeyi $\alpha<p$ olarak çıkmıştır. Bu başarı puanlarının normal dağılıma sahip olduğunu göstermektedir.

Çizelge 9. Hatırlama test normallik testi

\begin{tabular}{lcccccc}
\hline & \multicolumn{3}{c}{ Kolmogorov-Smirnov } & \multicolumn{3}{c}{ Shapiro-Wilk } \\
\hline & İstatistik & df & $\boldsymbol{p}$-value & İstatistik & df & $\boldsymbol{p}$-value \\
Deney Grubu & 0.141 & 30 & 0.134 & 0.945 & 30 & 0.121 \\
Kontrol Grubu & 0.180 & 30 & 0.140 & 0.912 & 30 & 0.170 \\
\hline
\end{tabular}

Çizelge 10'da istatistiksel olarak her iki gruba uygulanan hatırlama testleri arasında bir ilişkinin olup olmadığının belirlenmesi için, 0.05 anlamlılık düzeyi esas alınarak bağımsız örneklem $t$ testi uygulanmıştır. Uygulama sonrası serbestlik derecesi 58, $t$ ve $p$ değerleri ise sırasıyla 2.403 ve 0.019 olarak bulunmuştur. 0.05 anlamlılık düzeyi göz önünde bulundurulduğunda istatistiksel olarak iki grubun hatırlama test sonuçları arasındaki farkın önemli $(p<\alpha)$ olduğunu ortaya koymaktadır.

Çizelge 10. Hatırlama test gruplar arası bağımsız örneklem $t$ testi bulguları

\begin{tabular}{llcl}
\hline & \multicolumn{3}{c}{$\boldsymbol{t}$-test for equality of Means } \\
\hline & $t$ & $\mathrm{df}$ & $p$-value (2-tailed) \\
Başarı & 2.403 & 58 & 0.019 \\
\hline
\end{tabular}

\section{Grup İçi Bulgular}

$\mathrm{Bu}$ bölüm kapsamında ilk olarak Şekil 2'de görüldüğü gibi deney ve kontrol gruplarına uygulanmış olan ön, son ve hatırlama test aritmetik ortalama değerleri sunulmaktadır. Daha sonra uygulanan bu ön, son ve hatırlama testleri, kontrol ve deney grubu olmak üzere iki alt başlık altında irdelenecektir. 


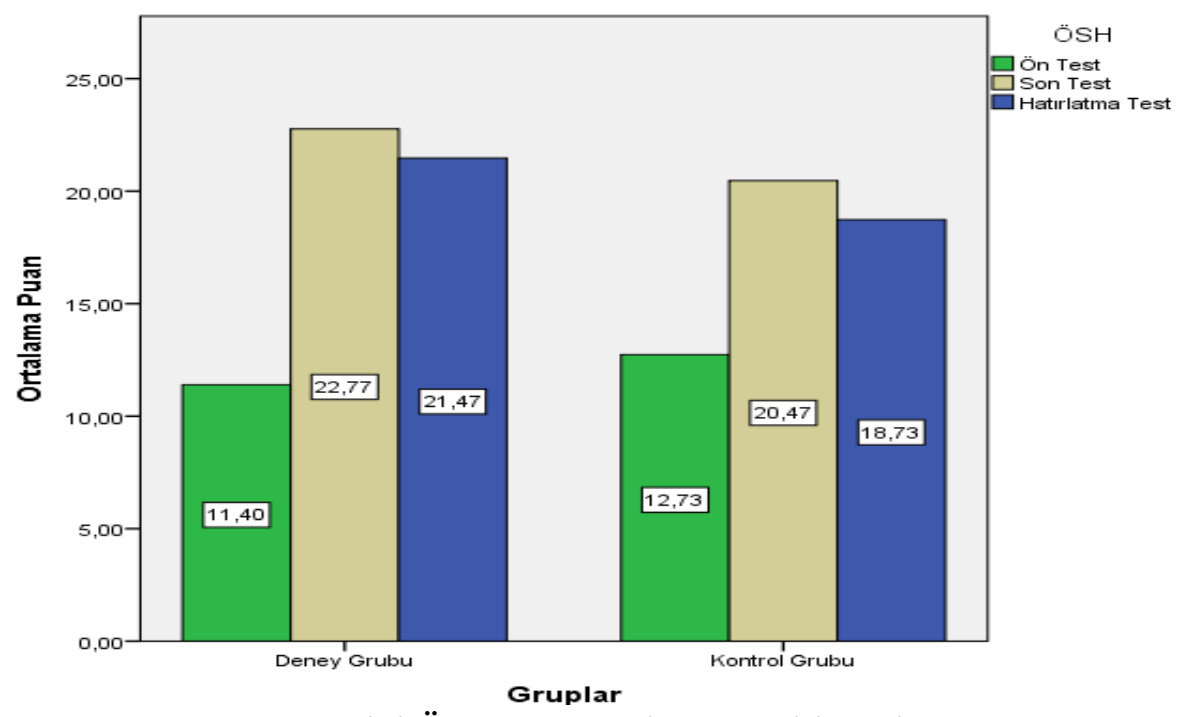

Şekil 2. Grup içi Ön-Son-Hatırlama testi karşılaştırması.

\section{Kontrol Grubu}

$\mathrm{Bu}$ araştırma kapsamında Çizelge 11'de klasik yöntem ile öğretim yapılan kontrol grubu deneklerine uygulanmış olan ön, son ve hatırlama testlerine ait bağımlı örneklem testi istatistik değerleri verilmektedir. Kontrol grubuna ait öğrencilerin ön test-son test, ön test-hatırlama test ve son test-hatırlama test sonuçlarına ait $t$ değerleri sırasıyla 7.638, 5.939 ve -2.718'dir. Ayrıca serbestlik derecesi 29 olan testlerin $p$ değerleri ise sırasıyla $0.000,0.000$ ve 0.011 olarak hesaplanmıştır. Böylece 0.05 anlamlılık düzeyi esas alındığında kontrol grubuna uygulanan ön test-son test, ön test-hatırlama test ve son test-hatırlama testleri arasındaki farkın istatistiksel olarak önemli olduğu görülmüştür. Öte yandan, öğretimden sonra sınıf ortalamasının arttığı, ancak bu gruba uygulanan öğretimin ortalama başarısının deney grubundan daha düşük olduğu görülmüştür.

Çizelge 11. Kontrol grubu bağımlı örneklem t testi sonuçları

\begin{tabular}{llccc}
\hline & & $\boldsymbol{t}$ & $\mathbf{d f}$ & $\boldsymbol{p}$-value (2-tailed) \\
\hline Pair 1 & Son Test - Ön Test & 7.638 & 29 & 0.000 \\
Pair 2 & Hatırlama Testi-Ön Test & 5.939 & 29 & 0.000 \\
Pair 3 & Hatırlama Testi- Son Test & -2.718 & 29 & 0.011 \\
\hline
\end{tabular}

\section{Deney grubu}

Çizelge 12'de materyal destekli yöntem ile öğretim sunulan deney grubu öğrencilerinin uygulanan ön, son ve hatırlama test sonuçlarına ilişkin bağımlı örneklem $t$ testi istatistik değerleri verilmektedir. Burada, deney grubu öğrencilerinin ön test-son test, ön test-hatırlama test ve son testhatırlama test sonuçlarına ilişkin $t$ değerleri sırasıyla 16.302, 13.968 ve -1.735 'dir. Ayrıca serbestlik derecesi 29 olan testlerin $p$ değerleri ise sirasıyla $0.000,0.000$ ve 0.930 olarak hesaplanmıştır. $\mathrm{Bu}$ durumda 0.05 anlamlılık düzeyi esas alındığında istatistiksel olarak deney grubuna uygulanmış olan ön ve son testleri arasındaki farkın önemli yine hatırlama test- ön test arasındaki farkın önemli; hatırlama test-son test arasındaki farkın ise önemsiz olduğu gözlenmiştir. Ön test ve son test ortalamaları arasındaki farkından da anlaşıldığı gibi, materyal destekli yöntem ile deney grubuna verilen öğretimin öğrencilerin başarısı üzerindeki olumlu etkisi açıkça görülmektedir. Diğer taraftan yapılan materyal destekli yöntem ile öğretim yapılan deney grubunun genel başarısının, klasik yöntem ile öğretim yapılan kontrol grubuna kıyasla daha yüksek olduğu açıkça görülmektedir. 
Çizelge 12. Deney grubu bă̆ımlı örneklem t testi sonuçları

\begin{tabular}{llccc}
\hline & & $\boldsymbol{t}$ & df & $\boldsymbol{p}$-value (2-tailed) \\
\hline Pair 1 & Son Test - Ön Test & 16.302 & 29 & 0.000 \\
Pair 2 & Hatırlama Testi-Ön Test & 13.968 & 29 & 0.000 \\
Pair 3 & Hatırlama Testi-Son Test & -1.735 & 29 & 0.930 \\
\hline
\end{tabular}

SONUÇ

Araştırma sonuçlarına göre; gruplar arası ortalamalar göz önüne alındığında, etkinlik çalışmaları öncesi başarı ortalaması düşük olan deney grubu deneklerinin, kontrol grubu deneklerine kıyasla başarı ortalamalarını arttırdıkları, son ve hatırlama testi sonuçlarında açıkça görülmektedir. Hatırlatma testi sonuçlarının istatistiksel olarak anlamlı bir farkın olması öğrenmelerin kalıcılı̆̆ı açsından materyal destekli öğretimin klasik öğretime göre daha yararlı bir yöntem olduğunu göstermektedir. Aynı şekilde grup içi değerlendirmeler, deney grubuna uygulanmış olan materyal destekli öğretim yöntemi ile öğretimin öğrenci başarısını klasik yöntem ile verilen öğretime kıyasla olumlu (pozitif) yönde arttırdı ğını ortaya koymuştur.

$\mathrm{Bu}$ çalışmada ulaşılan sonuçların ilköğretim 8. Sınıf öğrencilerinin LGS sınavına hazırlanma döneminde yapılması öğrencilerin etkinliklere odaklanmasına negatif yönde etkilemiştir. $\mathrm{Bu}$ durum çalışmayı bir açıdan sınırladığı söylenebilir. Yine öğrenciler yapılan görüşmelerde yapılan etkinlilerin matematiğe olan ilgilerinin artmasına ve matematik önyargılarının kırılmasına yardımcı olduğunu söylemişlerdir. Aynı şekilde materyal destekli öğretimin öğrencilerin bireysel öğrenmelerine katkı sunduğu, matematik dersine olan motivasyonu olumlu yönde artırdığı, arkadaşlarıyla öğrendiklerini paylaşmalarını kolaylaştırdığı ve öğrencileri aktifleştirdiği gözlenmiştir. Bu nedenle öğretmenlerin öğrenci merkezli materyal destekli öğretim yöntemine yönelmeleri ve bunun için gerekli hizmet içi eğitimleri almaları sağlanmalıdır. Ayrıca öğretmenlerin ölçme değerlendirme aşamalarında da materyal kullanmalarına yönelik teşviklerin artırılması gerekir.

\section{TEŞEKKÜR}

Bu çalışma, Van Yüzüncü Y1l Üniversitesi Bilimsel Araştırma Projeleri Koordinasyon Birimi tarafından "FYL-2019-8317" kodlu proje ile desteklenmiştir.

\section{Çıkar Çatışması}

Yazarlar arasında herhangi bir çıkar çatışması yoktur.

\section{Yazar Katkısı}

Yazarlar bu çalışma için eşit oranda katkı sağlamıştır.

\section{KAYNAKLAR}

Acar, C., 2005. Aktif Öğrenmenin Matematik Başarısı Üzerine Etkisi (Yayımlanmamış yüksek lisans tezi). Y. Y. Ü., Fen Bilimleri Enstitüsü, Van.

Altun, Y., 2016. Ortaöğretim matematik öğretiminde geleneksel öğretim ile etkinlik temelli öğretim yöntemlerinin öğrenci başarısı üzerindeki etkisi. Akademik Sosyal Araştırmalar Dergisi, 4(27): 466-485.

Aydın, B., Doğan, M., 2012. Matematik Öğretimi: Geçmişten Günümüze Matematik Önündeki Engeller. Batman Üniversitesi Yaşam Bilimleri Dergisi, 1(2): 89-95.

Baki, A., 2003. Matematikçiler Bülteni, Tr.Net, Sayı: 2. 
Bozkurt, A., Akalın, S., 2010. Matematik Öğretiminde Materyal Geliştirmenin ve Kullanımının Yeri, Önemi ve Bu Konuda Öğretmenin Rolü. Dumlupınar Üniversitesi Sosyal Bilimler Dergisi, 27: 47-56.

Cengizhan, S., 2008. Modüler Öğretim Tasarımının Farklı Öğrenme Stiline Sahip Öğrencilerin Akademik Başarılarına ve Öğrenme Kalıcılığına Etkisinin Belirlenmesi. Eğitimde Kuram ve Uygulama Dergisi, 4: 98-116.

Güler, H. K., Çakmak, D., Kavak, N., 2013. Karikatürlerle Yapılan Matematik Öğretiminin Öğrencilerin Akademik Başarılarına ve Tutumlarına Etkisi. Eğitim Fakültesi Dergisi, 26(1): 149-160.

Gündüz, S., Odabasi, F., 2004. Bilgi Çaginda Ögretmen Adaylarinin Egitiminde Ögretim Teknolojileri ve Materyal Gelistirme Dersinin Önemi. The Turkish Online Journal of Educational Technology, (TOJET), 3(1): 43-48.

Eygü, H., Karaman, S., 2013. Uzaktan Eğitim Öğrencilerinin Memnuniyet Algıları Üzerine Bir Araştırma. Kırıkkale Üniversitesi Sosyal Bilimler Dergisi, 3(1): 36-59.

Lerman, S., 2014. Encyclopedia of Mathematics Education. London South Bank University, London. 163.

MEB, 2018. İlköğretim (1-8. Sınıflar) Matematik Dersi Öğretim Programı. Ankara.

Moyer, P. S., 2001. Are we having fun yet? How teachers use manipulatives to teach mathematics. Educational Studies in Mathematics, 47: 175-197.

Olkun, S., Toluk, Z , 2003. İlköğretimde Etkinlik Temelli Matematik Öğretimi. ANI yayıncılık, Ankara. 320.

Özmantar F., Bingölbali E., 2009. Etkinlik Tasarımı ve Temel Tasarım Prensipleri, İlköğretimde Kavram Yanılgıları ve Çözüm Yolları. Pegem Akademi, Ankara.

Pesen, C., 2003. Matematik Öğretimi. Nobel Yayın Dağıtım, Ankara. 378.

Podolak, M., Młynarska, M., Kawałek, A., Śnieżek, W., Napiórkowska, G., 2014. Modern Methods of Teaching - Learning Mathematics and Related Subjects. Erasmus+, European Union.

Tabuk, M., 2003. İlköğretim 7. Sınıflarda “Çember, Daire Ve Silindir” Konusunun Öğretiminde Bilgisayar Destekli Öğretimin Başarıya Etkisi (Yayımlanmamış yüksek lisans tez). Marmara Üniversitesi, Eğitim Bilimleri Enstitüsü, İstanbul.

Uysal Koğ, O., 2012. Görselleştirme Yaklaşımı İle Yapılan Matematik Öğretiminin Öğrencilerin Bilişsel ve Duyuşsal Gelişimi Üzerindeki Etkisi (Yayımlanmamış doktora tezi). Dokuz Eylül Üniversitesi Eğitim Bilimleri Enstitüsü, İzmir.

Yıldız, R., 2004. Öğretim Teknolojileri ve Materyal Geliştirme. Konya, Atlas Kitabevi. 50-70. 